\title{
General Principles of Contract Law
}

\author{
Stephen F. Matthews and Timothy W. Triplett \\ Department of Agricultural Economics, University of Missouri-Columbia
}

Farmers make many different types of contracts each year. A contract is made when they hire someone to haul their hay. When they buy fertilizer on credit, or when they purchase a new tractor. Many farmers' day-to-day transactions are so commonplace that they give no thought to the fact that a contract is involved.

However, the existence of a contract implies that each party has certain legal rights and duties under the agreement. Each has a duty to perform his or her part of the contract and a right to expect the other party's full performance. The extent of these rights and duties varies, depending on the extent of a given contractual agreement.

This publication outlines some general principles of law that govern the performance of contracts. It is not intended to serve as a substitute for competent legal advice on a specific contractual problem.

\section{What is a contract?}

In this publication, a contract is an agreement between two or more parties which both parties are legally obligated to fulfill and for which either can go to court and receive some type of relief if the other does not meet the legal obligation. Thus, determining when the parties have a legal obligation or duty to carry out terms of an agreement is important.

Five factors must be present before a legal obligation exists. If any one of these five items is missing, an agreement does not constitute a legal contract and neither party is obligated to carry out its terms. Thus, these items are the essential elements of a contract:

1. Competent parties

2. Legal or proper subject matter

3. An offer

4. An acceptance

5. Consideration

Before you can determine if each of these elements is present, you need to know their legal meanings.

Competent parties. Before you are bound by the terms of a contract, you must give your consent to accept both the responsibilities and benefits contained in an agreement. Here the law protects people who lack the maturity or mental capacity to exercise good judgment. Thus, people under 18 years of age in Missouri, insane people and those considered mentally incompetent are not bound to their contractual agreements.

Even though these people have consented to a given agreement, the courts will not enforce it against them. The parties must be competent before a legal contract exists.

For instance, suppose a 16-year-old boy agrees to buy a car from you for $\$ 1,000$. If he backs out of the agreement and refuses to buy the car, you are not entitled to sue him. Legally, no enforceable contract ever existed because one of the essential elements, competent parties, was missing.

Legal or proper subject matter. A second essential element of a contract is the subject matter with which the contract deals: it must be both legal and proper. This requirement may be violated basically in three ways:

- The performance required may be illegal.

- The agreement itself may be illegal.

- The courts may refuse to enforce a contract as a matter of public policy, even though both the agreement and performance under the contract are legal. 
The following examples detail a few situations when contracts cannot be enforced because the essential element of legal or proper subject matter is missing.

If you enter into a contract that requires the performance of either a crime or a tort (injury done intentionally or negligently to a person or property, for which damages can be recovered in a civil law suit), this agreement cannot be enforced. For example, you cannot hire someone to murder, rob or assault someone else and sue him for damages if he fails to accomplish the task. Likewise, you cannot enforce a contract that calls for the other party to do some act which causes someone else damage and involves the commission of a tort.

An example of an illegal agreement might involve a contract between two competitive business firms under which each would restrict its business operations to a given geographical area. This may violate antitrust laws. If so, the subject matter is illegal and the contract is unenforceable.

The fact that some contracts may be unenforceable because they violate public policy is more difficult to illustrate. In general, courts will refuse to enforce agreements in which one party takes unreasonable advantage of a second party if the latter is in a weak bargaining position. This might happen under the following circumstances:

Suppose one party is a commercial processor of some farm specialty crop and that no other such processors are nearby. Further suppose that a farmer growing this specialty crop has made a sizable investment in unique machinery and equipment which cannot be used in any other farming operation and has little resale value.

Being aware of this fact, the processor might offer the farmer a contract under which the farmer could make little or no profit even under ideal growing conditions. The contract might also prohibit the farmer from selling the specialty crop to anyone else.

Since there are no other processors with which the farmer can contract, he or she knows the choice is either to sign this contract or else permit the machinery and equipment to stand idle. These circumstances might be called a "take it or leave it" situation. The economic realities of letting machinery stand idle may leave the farmer with little choice in the matter. The farmer may go ahead and sign the contract to produce the specialty crop.

Under these circumstances, if the farmer later breaches the contract, a court may refuse to enforce it. This might happen because of the public policy that one should not take unfair advantage of those in weak bargaining positions. A court may say it would be "unconscionable" to enforce the contract under these circumstances.

Offer. Another essential element of a contract is an offer. An offer is a promise that is conditional upon the other party:

- Doing some act

- Intentionally not doing some act

- Promising some return performance.

To illustrate each, first suppose you tell your neighbor, "I will pay you $\$ 50$ when you have finished plowing my 10 -acre field." Here, a legal offer has been made, because your promise to pay $\$ 50$ is conditional upon your neighbor doing an act - plowing your field.

The law does not require you to say "I promise to pay you $\$ 50$ when you have finished plowing my 10 -acre field." Rather a promise legally exists any time you say you will do something.

An offer also exists when your promise is made conditional on the other party intentionally not doing some act. For example, suppose a grove of trees that serves as a natural windbreak for your home is located on your neighbor's land. Further suppose that your neighbor is planning to cut down these trees to use the land for crop production. A legal offer would exist if you said to him, "I will pay you \$100 if you won't cut these trees."

A legal offer also exists when your promise is conditional upon the other party making a promise in return. This would exist, for example, if you said, "I will plow 30 acres of your corn land if you promise to combine 20 acres of wheat for me."

Sometimes, because of the language used, you may wonder whether an offer has been made. For instance, suppose someone says, "I might consider selling you my farm for $\$ 50,000 . "$ Is this an offer? 
Legally an offer is made anytime an ordinary person hearing such a statement would be led to believe the person making the statement was making a conditional promise. In case of a dispute that is taken to court, the jury decides whether an offer was made. If they decide no offer was made, there is no enforceable contract because an offer is an essential element of a contract.

Has an offer to sell been made when goods are to be sold at an auction? As a general rule, an auctioneer does not offer these goods for sale. Rather the auctioneer merely requests offers, and the bids are considered legal offers.

Likewise, advertisements in newspapers or on radio or television generally do not constitute legal offers, but rather are understood simply as requests to consider, examine or negotiate for purchase. However, language at an auction or in an advertisement that clearly indicates an offer to sell will be treated as such by the courts.

An offer is not legal until it is received. This is particularly important when an offer is made by mail. For example, suppose you mail a letter to someone, offering to sell your herd bull for $\$ 2,000$. However, before the other party received the letter, you call him on the telephone and say, "I revoke my offer to sell you my bull." Here, no legal offer was made, because you revoked it before it was received.

Further, suppose your letter said, "I will sell you my herd bull for $\$ 2,000$ if you accept within five days from the date of this offer." Since the offer is not legal until it is received, the five-day period begins on the date the letter was received.

An offer remains open for acceptance until:

- The offer is accepted or rejected by the party to whom the offer was made, or

- The offer is revoked by the party making the offer.

The party making the offer has the right to revoke it unless it is accepted before revocation or unless he or she is given some valuable consideration for keeping the offer open.

This agreement to keep an offer open for a period of time for valuable consideration commonly is referred to as an "option contract." An example of an option contract would be when A says to B, "I offer to sell you my herd bull for $\$ 2,000$; this offer will remain open for five days if you pay me $\$ 100$ for keeping the offer open this long," and B pays A the $\$ 100$.

Acceptance. Once an offer has been made, the other party must accept the offer to create a contract. Since an offer is a conditional promise, a legal acceptance must meet the conditions placed in the offer. The acceptance must be in the form requested in the offer. That is, the acceptance must either be the doing of an act, intentionally not doing an act or promising some performance, depending on the request in the offer.

For example, suppose your neighbor says, "I will give you $\$ 2,000$ if you will deliver your herd bull to my farm tomorrow. If you deliver the bull the next day, you legally have accepted his offer because you met the conditions of the offer. Delivery of a cow the next day or your bull two weeks later would not constitute a legal acceptance because neither meets the conditions of the offer.

Acceptance can only be made by the person to whom the offer was directed. Thus, if you offer to sell your tractor to John Doe, Richard Roe cannot step in and accept your offer.

If the offer requests a return promise, an acceptance becomes legal when the person accepting the offer puts the acceptance into the process of communication authorized by the offer. Common processes of communication often authorized include the telephone, telegraph, mail and direct oral communication.

An offer can expressly authorize that acceptance be made through any of these channels of communication simply by stating that the offer must be accepted in a certain manner. Or, it may implicitly authorize one to communicate acceptance through a given channel.

For example, suppose John Doe mails you an offer that states, "I will give you $\$ 2,000$ for your tractor if you promise to deliver it to my farm on the first of next month." Since he used the mail to make the offer, he has implied you should use the mail to send him your acceptance. Thus, you may legally accept his offer by mailing him a return letter saying, "I promise to deliver my tractor to your farm on the first of next month."

An acceptance of an offer that varies in its terms from that of the original offer operates as a counter-offer, resulting in a cancellation of the original offer. Then, the party making the original offer is left to accept or reject the counter-offer. 
Under the Uniform Commercial Code, as adopted in Missouri in 1965 (Chapter 400, Revised Statutes of Missouri, 1969), a "definite and seasonable" expression of acceptance sent to the original party making the offer will operate as an acceptance even though some terms of the acceptance differ from those of the offer in "minor" ways. In addition, if the conduct of both parties implies they recognize the existence of a contract, this is sufficient to establish a contract even though the contract was not a formally written one.

Further information on these rather technical exceptions to the general rule on what constitutes acceptance should br obtained from an attorney.

Remember, unlike an offer, an acceptance becomes legal at the time it is placed in the authorized method of communication. In the preceding example, your acceptance was legal when the letter was mailed. You cannot telephone John Doe and revoke your acceptance after the letter was mailed, even though he may not have received it yet.

Can silence be acceptance? Generally, the silence of one party cannot be interpreted as a valid and binding acceptance of an offer. Thus, an offer cannot force you to actively reject the offer.

For example, suppose John Doe says, "I will sell you my bull for $\$ 2,000$. If you do not want to buy the bull you should tell me so before the first of next month." Under the terms of this offer, if you remain silent and say nothing, you appear to have accepted the offer.

But the law recognizes that one who remains silent may not have intended to accept an offer by remaining silent. He might, for example, just forget to reject the offer by responding. Thus, silence alone never will be considered a legal acceptance unless prior dealings between the parties indicate silence was intended to serve as an acceptance. If in prior dealings you have carried out contracts with John Doe in which your silence served as acceptance, it will be treated as acceptance in this case.

As a general rule, the conditions placed on the offer cannot require acceptance by your doing some act that you ordinarily would do anyway. Thus, if John Doe says, "You may accept this offer by going to church on Sunday," the fact that you do attend church on Sunday does not constitute a legal acceptance of the offer. This is because you may have gone to church as a matter of course without intending to accept the offer.

Consideration. The final essential element of a contract is consideration. Since an offer is a promise, the fulfillment of which is conditional on an act, an intentional omission to act or a return promise, consideration might be defined as that which is given in exchange for doing an act, intentionally not doing an act or promising some performance.

Consideration must be legally sufficient. This means there must be two elements:

- A benefit and detriment to the person who accepts an offer, and

- A benefit and detriment to the person who makes an offer.

If a contract contains two promises, legally sufficient consideration must be found for both before a contract is enforceable. Consider the following examples.

John Doe says to you, "I promise to give you all my money on Saturday," to which you reply, "I accept your offer." If John does not give you his money, you cannot complain because no legal contract was created. In saying, "I accept," you did not act, made no return promise and did not intentionally fail to do any act. In short, you did nothing that would constitute a legal detriment to you in accepting.

To illustrate further, suppose you tell John Doe, "If you promise to dig the post holes for a new fence along my north boundary, I will give you every other hole." He replies, "I accept your offer." Here, there has clearly been an acceptance of your offer, because John has implicitly promised to dig the post holes. But there is no enforceable contract because the consideration is not legally sufficient. John receives no benefit from accepting your offer, because the post holes are not worth anything to him. Likewise, the existence of the post holes belonging to someone else would not be detrimental to your business activities.

Here your offer can be called an illusory promise. That is, while you have made a promise, it has no value.

An example of circumstances under which consideration is legally sufficient might be as follows: You tell John Doe, "I will give you $\$ 2,000$ for your herd bull." He replies, "I accept your offer." Here, both parties have made legal promises John to sell his bull and you to pay $\$ 2,000$.

John has suffered a legal detriment (giving up his bull) and received a legal benefit $(\$ 2,000)$. Likewise you have suffered a legal detriment (giving up \$2,000) and received a legal benefit (the bull). Thus, the consideration is legally sufficient and the contract is enforceable. 
If all five of the essential elements are present, a contract is usually binding. However, certain contracts must also be in writing in order to be enforceable.

\section{When Is a written contract required?}

The basic reason certain types of contracts are required to be in writing is to prevent fraud. For example, it would be relatively easy for a person to make a claim against the estate of a deceased person, because the decedent is no longer able to deny the existence of such contracts. Thus, the law requires certain types of contracts to be in writing to be legally enforceable. There are basically three types:

- Contracts taking more than one year to perform

- Contracts involving interest in land

- Contracts for the sale of goods (amounting to $\$ 500$ or more).

Contracts taking more than one year to perform. A written contract is not required if the terms of the contract would lead you to reasonably expect performance to be completed within a year. For example, suppose you orally contracted with someone to level 160 acres of your cropland for irrigation for a given sum of money. However, an extended period of bad weather prevents him from leveling the land within one year from the date of the contract. Since it appeared possible to perform the contract in one year, it would still be enforceable even though it was not in writing.

However, now suppose this contract was entered into on July 1 and the terms called for the land leveling to begin on October 1 the following year. Here it would not be possible to perform the contract because the one-year period is measured from the date of the agreement rather than from the date performance is to start. Under these circumstances, the contract must be in writing to be legally enforceable.

Contracts must always be in writing to be enforceable if they will not be performed fully within one year. For instance, suppose Smith and Jones enter into an agreement on January 1, 1993. Smith promises to deliver one carload of hay a month to Jones in November 1993, December 1993 and January 1994, no earlier than the 15th of each month. Since part of the contractual performance clearly will fall outside the one-year period, the contract must be in writing before either party can enforce it.

Contracts involving interests in land. Contracts that deal with any interest in land must be in writing before they are enforceable. This includes a contract to sell property, a contract to convey an easement and lease agreements.

Lease agreements that are not written are considered to be a tenancy at will. This means that either the landlord or the tenant can terminate the oral lease by giving the other "legal notice." The length of time required to give legal notice varies, depending on the type of property involved.

In general, a tenancy at will from year to year for agricultural land can be terminated by the landlord by giving the tenant written notice not less than 60 days before the end of the rental year. Tenancies on a month-to-month basis can be terminated by giving written notice of one month. If you have questions about this, direct them to your attorney.

There is one exception to the rule that land sale contracts must be in writing to be enforceable. If, in the eyes of the law, a purchaser of land has partially fulfilled the oral contract to purchase the land, the contract is enforceable.

Basically, partial performance may be found if:

- The purchaser is in possession of the land by reason of the oral contract,

- The purchaser has made part payment of the purchase price, and

- The purchaser has made some improvement on the property.

For example, suppose you make an oral contract to buy John Doe's farm. Ordinarily a land sale contract is not enforceable unless it is in writing. However, the law recognizes that a written instrument is not a necessity if no danger of fraud is involved. Thus, an oral contract to buy John's farm will be declared enforceable if you have made part payment, are in possession and have constructed improvements. 
Contracts for the sale of goods. Since Missouri adopted the Uniform Commercial Code, a contract for the sale of goods for $\$ 500$ or more generally is not enforceable unless there is some writing sufficient to indicate that a contract for a sale was made between the parties. This writing must be signed by the party against whom enforcement of the contract is sought. However, some court decisions have held that partial performance of an oral contract (such as acceptance of the goods contracted for) removes the contract from the writing requirement and is enforceable. However, the general rule is that writing is required for sales involving $\$ 500$ or more.

The critical question in this legal area is: "What types of personal property legally are considered goods?" Goods are defined by the Uniform Commercial Code as all things that are movable at the time of identification in the contract (other than money and investment securities). Goods do include the unborn young of animals and growing crops and probably livestock and harvested grain.

Several other kinds of contracts also must be in writing. Among these are secured loan agreements, assignments of future earnings, assignments of leases or other interests in land and some agency contracts. Contracts involving the sale of securities must always be in writing, no matter what the price, to be enforceable. Contracts for the sale of other intangible personal property with a value of $\$ 5,000$ or more must also be in writing.

As a practical matter, all contracts should be in writing. If all terms are clearly set out in a written instrument, misunderstandings are less likely to arise at some later date.

Most people we deal with in business are basically honest. To most, a handshake is as binding as a written instrument. But placing an agreement in writing should not be taken as an indication that the parties do not trust each other. Rather, it is simply good business. For instance, even though both parties to a contract have complete faith in each other, either could die before the contract is completed. If the contract is the type the law requires to be in writing, the survivor has no recourse against the decedent's estate unless there is a written agreement.

\section{When may performance be excused?}

Courts recognize that requiring full and complete performance of all contractual terms may be impossible, impractical or illogical under some circumstances. On the other hand, they also recognize the importance of protecting a person's contractual rights. To avoid the unreasonable result of requiring perfect and full performance of all contracts, the courts have developed several doctrines which may excuse persons from full and exact contractual performance under some circumstances. Some of these doctrines are discussed here. None are hard and fast rules that will be followed in every situation.

Substantial performance. Generally, if one has substantially fulfilled a contract, he or she is excused from further performance. Substantial performance means a performance that is something less than full and exact compliance with the contract's terms. It refers to an incomplete yet substantial discharge of contractual duties.

In determining whether substantial performance has occurred, courts look at the extent or value of nonperformance and compare it with the amount of performance that has occurred. If those duties which one has not performed are relatively small, then the substantial performance doctrine comes into play.

For example, if a person promised in a written contract to clean a certain room once a week for a five-year period and unintentionally missed one week during that period, this would probably be considered substantial performance. Of course, payment for the missed week of work would not be required of the other party.

Note, however, the doctrine of substantial performance cannot be used as an excuse for purposely not fulfilling legal duties under a contract. The substantial performance doctrine generally is used by the courts only when necessary to prevent an undue hardship on a party who in good faith has tried to fulfill all contractual duties.

Impossibility of performance. Whenever performance depends on the continued existence of a person or thing, destruction of that thing through no fault of the contracting parties releases both from their obligations. The same rule also has been applied where an ability to perform the contract depends on the happening of an event over which neither party has control.

For example, suppose you contract with a grain elevator to deliver a certain amount of grain at a future date to be grown on a specific tract of your land. If extreme weather conditions destroy the crop so you cannot deliver some or any grain from that field, a court may decide you are excused from performance of the contract due to impossibility of performance.

However, grain elevator contracts generally do not provide that the grain to be delivered is to come from a certain tract of land. 
Under these types of contracts, not being able to deliver the contracted amount of grain generally is not excused due to impossibility of performance. The farmer in this situation would have to "cover" the shortage with grain obtained elsewhere or be liable for damages resulting from this shortage.

Impossibility of performance may arise from destruction of the subject matter of a contract, a law which makes the contract illegal, or in the case of a personal service contract, death of the party promising to perform services. Temporary impossibility may also a rise when, for example, a party to a contract for personal services becomes ill or disabled. If this occurs, she or he would not be required to work during the period of illness or disability.

Frustration of purpose. If the value of the performance that you have bargained for is destroyed by a supervening event, the contractual obligations are dismissed as long as the frustrating event was not foreseeable at the time the parties contracted.

Assume you promise to pay John Doe $\$ 100$ if John will allow you to use his rooftop to view a parade in which the President will ride.

If the President fails to come to the community and the parade is called off, your duty to pay John $\$ 100$ may be excused.

Or further, suppose you hire your neighbor to combine 40 acres of soybeans, but the beans are destroyed by a flood before they are ready to harvest. Assuming the flood was not foreseeable at the time you entered into the contract, neither party is obligated to perform because the flood has frustrated the purpose of the contract.

\section{Implied contracts}

The contracts discussed so far have been express contracts, or those to which the parties explicitly have agreed. Courts also have said some contracts are "implied in law" and some are "implied in fact." When you know compensation is expected and you sit by and watch another perform services that benefit you, a contract may be implied. Under these circumstances, if you accept the benefit of another's labor, you may have implicitly promised to pay for such benefit.

For example, if you knowingly let someone spray paint the exterior of your grain bin with aluminum paint, and you know they have mistaken your grain bin for your neighbor's bin, a court might find an "implied in law" contract. If so, you would be liable for the value of the improvement to your grain bin.

\section{Remedies for breach of contract}

Two basic remedies are available when another party breaches a contract with you. They are:

- A lawsuit for damages

- A lawsuit for specific performance.

If you choose to sue for damages, you essentially are asking the guilty party to pay enough money to put you in the financial position in which you would have been if he had carried out his contractual obligations. You have the burden of proving how much money is required to place you in this position.

Because it takes time and money to bring a lawsuit and prove contract damages, many contracts contain what is called a liquidated damages clause. This clause simply states how much money the innocent party will receive as damages if the other party breaches the contract. Since this is a part of the contractual agreement, the clause has the practical function of determining the extent of damages and perhaps of avoiding the necessity of a lawsuit. Thus, the basic purpose of a liquidated damages clause is to avoid the expense and burden of proving contract damages in court. These clauses are generally valid and enforceable as long as they represent a reasonable attempt at the time the contract was entered into to determine the extent of actual damages that would occur if the contract were broken.

Courts will not, however, enforce a liquidated damages clause if they determine the amount set is unreasonably large and actually a "penalty" for not performing the contract as agreed.

If an action for damages cannot adequately compensate the innocent party for his loss under the contract, then he can sue for specific performance. In this kind of lawsuit, you are asking the court to require the other party to "specifically perform" or carry out his duties as stated in your contract. 
Damages are considered inadequate to compensate you when the subject matter of the contract is unique. In general, this means you can sue for specific performance when the subject matter is not readily available elsewhere. Some examples might be contracts for the sale of antiques, rare art objects or family heirlooms. In addition, land is always considered unique. If you have a written contract to buy a farm, you could initiate a lawsuit for specific performance to force the seller to carry out his contractual duties and convey title to you. However, contracts between you and another person to perform personal services are never specifically enforceable.

\section{Checklist}

This publication merely outlines a few general rules and principles affecting the validity of contracts. Many exceptions exist. To avoid potential lawsuits, you may want to have your attorney draft or review your contracts before you enter into final agreements. Ask yourself several basic questions before making contracts.

1. Are the five essential elements present? That is, are there competent parties, legal or proper subject matter, an offer, an acceptance and consideration?

2. Do you need to put the agreement in writing to ensure its enforceability?

3. Does the agreement cover everything that it should?

4. Are all the terms clear to you?

5. Should you have a liquidated damages clause inserted in the contract?

6. Did you get a signed copy of the contract?

The old adage, "An ounce of prevention is worth a pound of cure," is particularly true for contracts. Asking your attorney to assist you in contractual matters can prevent lawsuits in the future.

This publication is a revision of an earlier publication by Donald Levi and John Holstein.

To order, request G00425, General Principles of Contract Law (out of print).

- Issued in furtheranœ of Cooperative Extension Work Acts of May 8 and June 30, 1914, i n copperation with the United States Department of Agriculture. Ronald J. Turner, Director, Cooperative Extension Service, University of Missauri and Lincoln University, Columbia, Missauri 65211 • Uni versity Extension does not discriminate on the basis of race, color, national origin, sex, religion, age, disability or status as a Vietnamera veteran in employment or program s. • If you have special needs as addressed by the Americans with Disabilities Act and need this publication in an alternat ive format, write ADA Officer, Extension and Agricultural Information, 1-98 Agriculture Building, Columbia, MO 65211, or call (573) 882-8237. Reasconable efforts will be made to accommod ate your special needs. 